\title{
Soy Lecithin/Glycerol Dioleate-based Oral Spray
}

National Cancer Institute

\section{Source}

National Cancer Institute. Soy Lecithin/Glycerol Dioleate-based Oral Spray. NCI

Thesaurus. Code C103181.

An oral spray containing soy phospholipid and glycerol dioleate, with protective, analgesic and anti-mucositic activities. Upon spraying onto the oral mucosal surface and contact with saliva, the soy lecithin/glycerol dioleate-based oral spray forms a gel and adheres to the mucosal surfaces thereby forming a lipid film. This provides a protective barrier and an analgesic effect within the oral cavity. In addition, the lipid barrier prevents bacterial growth at affected areas thereby decreasing infection risk. 